\title{
Effects of High Ambient Temperature and Bypass Protein Supplementation on Performance of Crossbred Lambs
}

\section{(Pengaruh Temperatur Lingkungan dan Suplementasi Bypass Protein Terhadap Performans Domba Merino Persilangan)}

\author{
Dahlanuddin $^{1)}$, C.J. Thwaites ${ }^{2)}$ and J.V. Nolan ${ }^{2)}$ \\ 1) Faculty of Animal Science University of Mataram, Jl. Majapahit 62. Mataram 83125 Lombok, Nusa \\ Tenggara Barat. Telpon (0370) 633603; Fax (0370) 640592 \\ 2) Faculty of Animal Science University of New England, Armidale, NSW, Australia \\ e-mail: dahlan.unram@gmail.com
}

Diterima; 4 April 2016/Disetujui: 25 Mei 2016

\begin{abstract}
The objective of this experiment was to study the effect of dietary supplementation with a source of bypass protein (cottonseed meal, CSM) on the performance of growing crossbred wethers fed low digestibility roughage at high ambient temperature. Sixteen unshorn Border Leicester x Merino lambs aged 6 months and weighing $24.9 \pm 0.37 \mathrm{~kg}$ were allocated into a $2 \times 2$ factorial design $(2$ diets and 2 ambient temperatures). Each group was fed either wheaten chaff $+2 \%$ urea ad libitum or wheaten chaff + $1 \%$ urea ad libitum $+100 \mathrm{~g} / \mathrm{d}$ cottonseed meal. The results show that respiration rate and rectal temperature were significantly affected by ambient temperature $(\mathrm{P}<0.01)$, but not by diet. Total dry matter intake was significantly higher $(\mathrm{P}<0.01)$ at lower temperature than at high temperature, and significantly higher $(\mathrm{P}=0.04)$ on the supplemented diet than on the control diet. Water intake tended $(\mathrm{P}=0.06)$ to be higher on the CSM+ diet than on the control diet, and was significantly at greater $(\mathrm{P}<0.01)$ high ambient temperature than at low temperature. The concentration of $\mathrm{NH}_{3}-\mathrm{N}$ in the rumen fluid (ranged from $310 \pm 17$ to $413 \pm 20$ $\mathrm{mg} \mathrm{N} / \mathrm{L}$ ) did not differ significantly either between diets or ambient temperatures. Blood plasma urea nitrogen concentration was significantly higher in sheep on the control diet than in those on the supplemented diet, and at low than high temperature. The organic matter digestibility was not significantly affected by temperature and diet. The rate of live weight gain was significantly $(\mathrm{P}<0.01)$ reduced by high ambient temperature and the interaction between diet and temperature was significant $(\mathrm{P}<0.01)$. At low temperature, lambs on the supplemented diet grew significantly faster than those on the control diet, but not at high temperature. In conclusion, high ambient temperature increases respiration rate, rectal temperature and water intake but reduces dry matter intake and live weight gain. Supplementation with $100 \mathrm{~g} / \mathrm{d}$ of cottonseed meal could not outweigh the depressing effects of constant high ambient temperature and humidity imposed in this experiment.
\end{abstract}

Key-words: ambient temperature, low quality diet, sheep, growth rate

\section{INTRODUCTION}

It has been suggested that fermentation of low quality forages produces high ratios of acetate to total volatile fatty acids in the rumen (Orskov and MacLeod, 1990; France and Siddons, 1993). Under tropical environments, specifically of low crude protein intakes of roughage diets, a combined effect of the products of fermentation of low quality roughage such as acetate together with the direct effects of high ambient temperature and humidity, may increase the total heat load on an animal. This may force an animal to reduce its feed intake in order to avoid additional heat stress (Leng, 1990).

A theory proposed by Leng (1990) predicts that supplementation of such an animal with bypass protein may improve the protein to energy ratio of the absorbed nutrients resulting in a more efficient use of acetogenic substrates. This may reduce the total heat load, and if so the animal's feed intake might then be maintained, or even increased.

The experiment reported in this paper was thus designed to study the effect dietary supplementation with a source of bypass protein (cottonseed meal, CSM) on the performance at 
high ambient temperature of growing crossbred wethers fed low digestibility roughage. As it was not possible to obtain typical tropical feeds (tropical grasses or rice straw) at Armidale, Australia when the experiment was conducted (a period of severe local drought), chaffed wheaten hay which contained no grain was used instead.

\section{MATERIALS AND METHODS}

Sixteen unshorn Border Leicester $\mathrm{x}$ Merino lambs aged 6 months and weighing $24.9 \pm 0.37 \mathrm{~kg}$ were allocated into a $2 \times 2$ factorial design ( 2 diets and 2 ambient temperatures). Each group was fed either wheaten chaff $+2 \%$ urea ad libitum or wheaten chaff $+1 \%$ urea ad libitum $+100 \mathrm{~g} / \mathrm{d}$ cottonseed meal. The CSM supplement was fed once daily, togeher with morning feeds. Animals from each diet treatment were randomly divided into two groups: the first group was housed in a climate chamber at $17 \pm 3^{\circ} \mathrm{C}$ and the other group in a second climate chamber at $35 \pm 2^{\circ} \mathrm{C}$. The relative humidity in these two climate chambers was maintained at $65 \%$. Both rooms were illuminated daily from 06.00 to $18.00 \mathrm{~h}$. Animals were penned individually. Feed was provided once daily ( at 08.30 ) at a level of about $15 \%$ in excess of previous day's intake, and drinking water was freely available at all times.

The experiment lasted for 8 weeks after a 3week adaptation period. Feed intake (FI - to measure dry matter intake, DMI) and water intake (WI) were recorded daily. Measurements of rectal temperature (RT) and respiration rate (RR) were taken every fourth day (at 14.00-15.00 h). Faecal collection for determination of organic matter digestibility (OMD) was carried out for 7 consecutive days in week 6 . Liveweight was recorded weekly before feeding to estimate daily live weight gain (LWG). During week 8, samples of blood (by jugular venipuncture), to measure blood plasma urea level, and of rumen fluid (by stomach tube, at $3 \mathrm{~h}$ after feeding), to measure rumen ammonia nitrogen $\left(\mathrm{NH}_{3}-\mathrm{N}\right)$ concentration, were collected.

\section{Statistical analysis}

Data were subjected to analyses of variance (ANOVA) for a factorial design. All data analyses were performed on the Minitab 8.2 computer program (Ryan et al., 1985).

\section{RESULTS AND DISCUSSION}

\section{Thermoregulatory responses}

Thermoregulatory responses of lambs to temperature and diet were measured in terms of RR and RT. RR was significantly affected by ambient temperature $(\mathrm{P}<0.01)$, but not by diet (Table 1 and Figure 2).

Table 1. DMI (g/d), WI (L/d), RR (resp/min), RT ( $\left.{ }^{\circ} \mathrm{C}\right)$, and LWG (g/d) of crossbred lambs fed wheaten chaff $+2 \%$ urea (control) or wheaten chaff $+1 \%$ urea $+100 \mathrm{~g} \mathrm{CSM} / \mathrm{d}$ (CSM+) at low and high ambient temperature (mean $\pm \mathrm{SE}, \mathrm{N}=4)$.

\begin{tabular}{lccccccc}
\hline & \multicolumn{2}{c}{$17 \pm 3{ }^{\circ} \mathrm{C}$} & \multicolumn{2}{c}{$35 \pm 2{ }^{\circ} \mathrm{C}$} & \multicolumn{3}{c}{$\mathrm{P}$ value } \\
\cline { 2 - 8 } & Control & CSM+ & Control & CSM+ & T & D & TxD \\
\hline RR & $92 \pm 8$ & $90 \pm 3$ & $202 \pm 6$ & $180 \pm 12$ & .00 & .21 & .31 \\
RT & $39.4 \pm .03$ & $39.6 \pm .08$ & $40.8 \pm .07$ & $40.9 \pm .05$ & .00 & .07 & .55 \\
DMI & & & & & & & \\
Chaff & $783 \pm 11$ & $837 \pm 35$ & $590 \pm 47$ & $525 \pm 43$ & .00 & .89 & .13 \\
Chaff +CSM & $783 \pm 11$ & $926 \pm 35$ & $590 \pm 47$ & $614 \pm 43$ & .00 & .04 & .13 \\
& & & & & & & \\
WI & $1.8 \pm .05$ & $2.2 \pm .14$ & $2.9 \pm .33$ & $3.8 \pm .50$ & .00 & .06 & .45 \\
LWG & $45 \pm 6$ & $85 \pm 8$ & $-9 \pm 5$ & $-27 \pm 11$ & .00 & .18 & .00 \\
\hline
\end{tabular}

$\mathrm{T}=$ temperature effect; $\mathrm{D}=$ diet effect; $\mathrm{TxD}=$ Interaction

The interaction between diet and ambient temperature was non-significant on RR. RT was also significantly $(\mathrm{P}<0.01)$ higher at higher ambient temperature. RT of lambs on the CSM+ diet tended to be higher than that of those on the control diet, but the difference only approached significance $(\mathrm{P}=0.07)$. The interaction between diet and ambient temperature was also nonsignificant. 

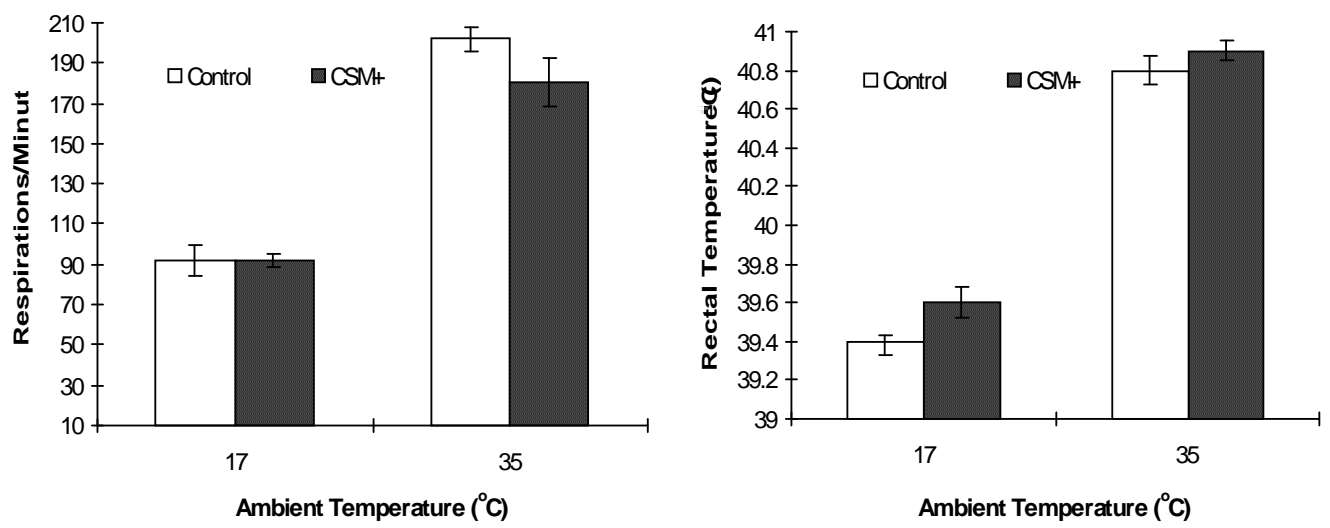

Figure 2. Effect of ambient temperature and diet on RR and RT of crossbred lambs (mean $\pm S E, N=4$ ).

RR and RT significantly increased with ambient temperature regardless of the type of diet. These changes were part of the strategy of the animals to dissipate body heat (Yeates et al., 1975). The relatively high ambient temperature and humidity set in this experiment limited the ability of the animals to reduce body heat through conduction, convection and radiation since the ambient temperature approximated RT. Evaporative cooling by means of increasing RR is an effective strategy for heat-stressed sheep (Johnson, 1987), limited to some extent by the relative humidity experienced. Irrespective of the details of the changes in RR and RT, the actual values recorded indicate that the level of heat stress experienced by the sheep at $35^{\circ} \mathrm{C}$ was comparable to that observed in the field in the tropics. It is concluded, therefore, that the ambient temperature / humidity regime adopted was successful in mimicking tropical conditions.

\section{Feed and water intake}

DMI of chaff was significantly higher $(\mathrm{P}<0.01)$ at low than at high temperature but the difference between diets and the interaction between diet and temperature were not significant. Total DMI (chaff+CSM), on the other hand, was significantly higher $(\mathrm{P}<0.01)$ at lower temperature than at high temperature, and significantly higher $(\mathrm{P}=0.04)$ on the + CSM diet than on the control diet. The interaction between diet and temperature was again non significant.

The overall WI tended $(\mathrm{P}=0.06)$ to be higher on the CSM+ diet than on the control diet. WI at high temperature was significantly $(\mathrm{P}<0.01)$ greater than at low temperature. However, the interaction between diet and temperature was non significant on WI (Figure 3).
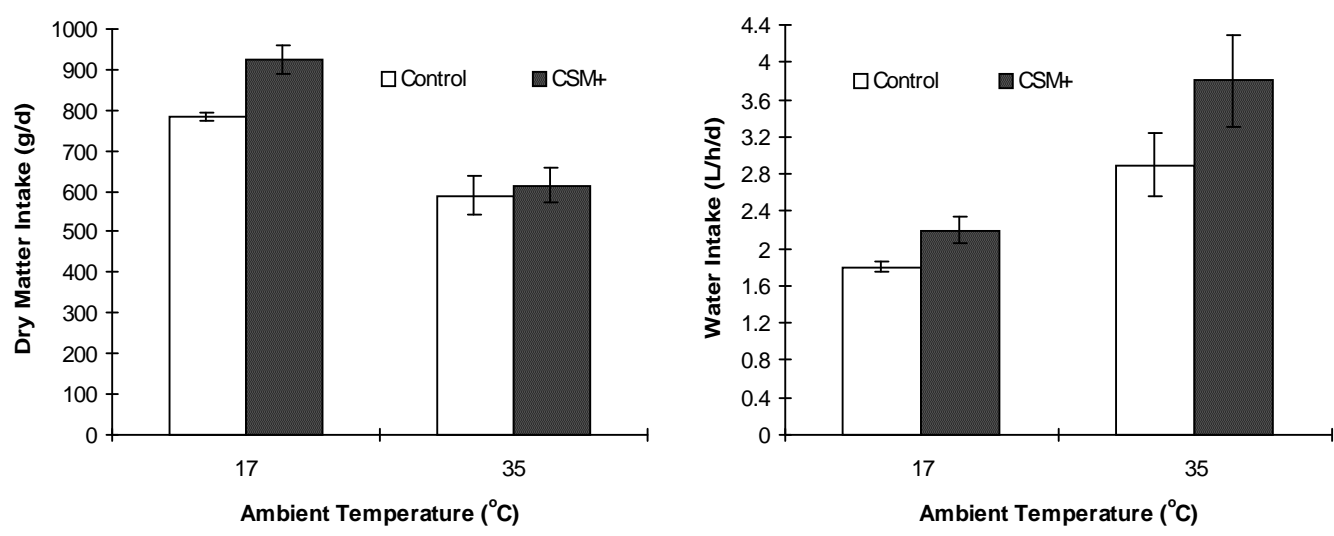

Figure 3. Effects of ambient temperature and diet on DMI and WI of crossbred lambs (mean $\pm \mathrm{SE}, \mathrm{N}=4$ ). 
In general, DMI declined but WI increased with increased ambient temperature. Significantly higher DMI on the CSM+ diet at low ambient temperature was probably a result of increased $\mathrm{P} / \mathrm{E}$ ratio in the absorbed products of rumen digestion in the lambs supplemented with cottonseed meal (Preston and Leng, 1987).

Reduced DMI in both treatments at high ambient temperature was presumably an important strategy adopted by the sheep to minimise their heat production and thus control their body temperature. Acetic acid, which provides energy for most animal tissues (and heat as a product of metabolism, especially in animals given low protein diets), is preferentially produced in low digestibility diets. Heat generated from the fermentation of fibre in low quality forages which contain inadequate levels of protein would be expected to create an additional heat load as a result of the so called 'futile cycles' of acetate metabolism in animals at high ambient temperature (Leng, 1990). Bhattacharya and Hussain (1974) also reported that reductions in DMI and in the utilisation of energy by sheep at high ambient temperature became more severe as the proportion of roughage was increased. While it is acknowledged that there is no simple relationship between RR, RT and DMI and the rate of heat production, the non-significantly different $\mathrm{RR}, \mathrm{RT}$ and DMI between diets observed at high ambient temperature in the present experiment strongly sugges that under the controlled condition used heat production was not reduced by CSM supplementation. Additional protein from the CSM supplement apparently could not outweigh the negative effects of high temperature. The reduced DMI at high ambient temperature can also be attributed to reductions in thyroid activity due to long-term exposure to heat (Yousef and Johnson, 1985).

Increased voluntary WI at elevated ambient temperature was probably associated with increased needs for thermoregulation (Bianca $e t$ al., 1965), for maintaining body water balance in the face of an increased water loss through both respiration (Appleman and Delouche, 1958) and other evaporative cooling mechanisms such as sweating. The slightly elevated WI on the $\mathrm{CSM}+$ diet was probably related to the protein and/or salt content of this supplement, both of which would require more water for excretion of metabolic wastes.

\section{Rumen ammonia concentration}

The concentration of $\mathrm{NH}_{3}-\mathrm{N}$ in the rumen fluid (Table 2) did not differ significantly either between diets or ambient temperatures. The mean values from 3 measurements made on weeks 2,6 and 8 ranged from $310 \pm 17 \mathrm{mg} \mathrm{N} / \mathrm{L}$ in sheep given the CSM supplemented diet at high temperature to $413 \pm 20 \mathrm{mg} \mathrm{N} / \mathrm{L}$ for the control diet at low temperature.

Table 2. Rumen $\mathrm{NH}_{3}-\mathrm{N}$ (3 h after feeding; mg N/L), plasma urea $\mathrm{N}(\mathrm{mg} \mathrm{N} / 100 \mathrm{ml}$ ) and organic matter digestibility (OMD, \%) of crossbred lambs fed wheaten chaff $+2 \%$ urea (control) or wheaten chaff $+1 \%$ urea $+100 \mathrm{~g} \mathrm{CSM} / \mathrm{d}(\mathrm{CSM}+)$ at low and high ambient temperature (mean $\pm \mathrm{SE}, \mathrm{N}=4)$

\begin{tabular}{lccccccc}
\hline & \multicolumn{2}{c}{$17 \pm 3^{\circ} \mathrm{C}$} & \multicolumn{2}{c}{$35 \pm 2{ }^{\circ} \mathrm{C}$} & \multicolumn{3}{c}{ P value } \\
\cline { 2 - 8 } & Control & CSM+ & Control & CSM+ & T & D & TxD \\
\hline $\mathrm{NH}_{3}-\mathrm{N}$ & & & & & & & \\
week 2 & $387 \pm 24$ & $373 \pm 21$ & $355 \pm 21$ & $342 \pm 21$ & .49 & .75 & .99 \\
week 6 & $428 \pm 25$ & $345 \pm 22$ & $394 \pm 22$ & $302 \pm 22$ & .42 & .08 & .93 \\
week 8 & $425 \pm 24$ & $401 \pm 21$ & $399 \pm 21$ & $286 \pm 21$ & .13 & .14 & .32 \\
mean & $413 \pm 20$ & $373 \pm 17$ & $383 \pm 17$ & $310 \pm 17$ & .20 & .13 & .60 \\
Plasma urea N & $31.3 \pm .74$ & $28.6 \pm .53$ & $19.1 \pm 2.10$ & $12.3 \pm 1.49$ & .00 & .01 & .20 \\
OMD & $62.4 \pm 1.13$ & $66.1 \pm .63$ & $59.0 \pm 3.25$ & $63.0 \pm 2.75$ & .21 & .14 & .94 \\
\hline
\end{tabular}

$\mathrm{T}=$ temperature effect; $\mathrm{D}=$ diet effect; $\mathrm{TxD}=$ Interaction

Rumen $\mathrm{NH}_{3}-\mathrm{N}$ concentrations were higher than the suggested optimum level of $250 \mathrm{mg} \mathrm{NH}_{3}-\mathrm{N}$ (Preston and Leng, 1987) at all sampling times. These high concentrations could be expected to be non-limiting for microbial fermentation in all treatments and thus to have minimised any possible confounding effects of different ammonia 
concentrations with the effect of level of CSM provided in the diet.

\section{Plasma urea nitrogen}

Blood plasma urea nitrogen concentration was significantly higher $(\mathrm{P}<0.01)$ at low ambient temperature than at high ambient temperature
(Table 2). The concentration was also higher $(\mathrm{P}=0.01)$ in the control group than in the CSM+ group. The interaction between temperature and diet, however, was not significant on plasma urea concentration. Figure 5 illustrates the relationship between blood plasma urea nitrogen and rumen ammonia nitrogen in the lambs in Experiment 1.

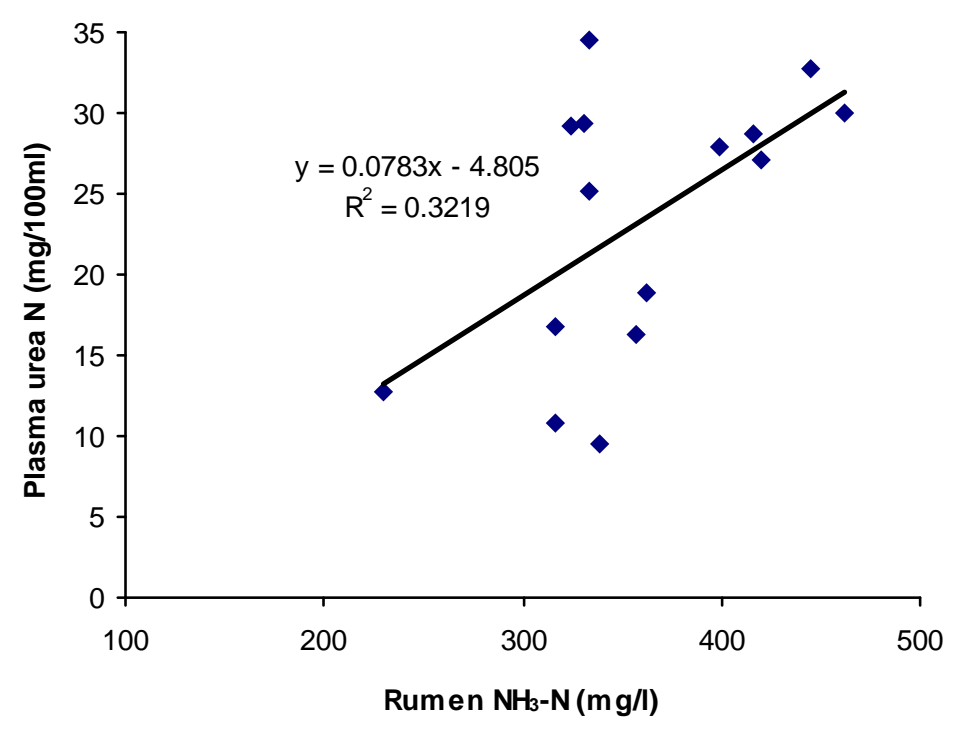

Figure 5. Relationship between rumen ammonia $\mathrm{N}$ and blood plasma urea $\mathrm{N}$ in crossbred lambs in Experiment 1 (data were pooled from both temperatures and diets).

Blood plasma urea nitrogen concentration was significantly higher in sheep on the control diets than in those on the CSM diet, and at low than high temperature. The concentration of $\mathrm{NH}_{3}-\mathrm{N}$ in the rumen may, to some extent, have contributed to the observed differences in blood urea $\mathrm{N}$ concentration (Figure 5). Similarly, the reduction in plasma urea $\mathrm{N}$ can be attributed to reduced feed intake (McDowell et al., 1969). From an extensive review Habeeb et al. (1992) concluded that blood plasma urea- $\mathrm{N}$ in ruminants decreases during heat stress; possibly due to increased recycling of urea$\mathrm{N}$ to the rumen to compensate for any reduced rumen ammonia $\mathrm{N}$ level as a result of depression in feed intake. This explanation does not appear to apply in the current work, however, for rumen ammonia $\mathrm{N}$ levels in all groups were high (Table 2). The plasma urea concentration in the present experiment apparently related to low DMI and thus $\mathrm{N}$ intake when ambient temperature was high. Habeeb et al. (1992) also suggested that the reduction in blood urea-N at high ambient temperature may be due to increased excretion of urinary nitrogen. Unfortunately, urinary nitrogen excretion was not measured in the present experiment.

\section{Feed digestibility}

As shown in Table 2, the digestibility of organic matter was consistently depressed by ambient temperature and the values on the $\mathrm{CSM}+$ diet were generally higher than on the control diet at both ambient temperatures. However these differences were not significant.

Feed digestibility was not affected by either ambient temperature or CSM supplementation in the current experiment. It is likely that the more than adequate soluble nitrogen provided in the form of urea in both diets (as indicated by the ruminal $\mathrm{NH}_{3}-\mathrm{N}$ concentration) ensured optimal fermentation in the rumen on all treatments. Leng et al (1993) suggested that a concentration of ammonia in the rumen of above $80 \mathrm{mg} \mathrm{NH}_{3}$ $\mathrm{N} / 1$ rumen fluid will have little further effect on feed digestibility, and the levels recorded in the present experiment were considerably above that suggested threshold. 
The level of DMI is, however, commonly recognised as a major factor affecting the rate of passage and mean retention time of digesta and hence digestibility of a feed (Christopherson, 1985), and digestibility could thus be expected to increase with reductions in DMI. However, Beede and Collier (1986) suggested that the advantage due to increased digestibility is generally offset by depressed feed intake, resulting in lower availability of nutrients. In the present study, however, a significant reduction in DMI at high ambient temperature did not increase digestibility. It appears likely that the significantly higher WI of sheep at high ambient temperature could have increased the rate of rumen wash out and hence reduced the mean retention time, and reduced digestibility. These factors may thus have countered the opposing influence of reduced DMI

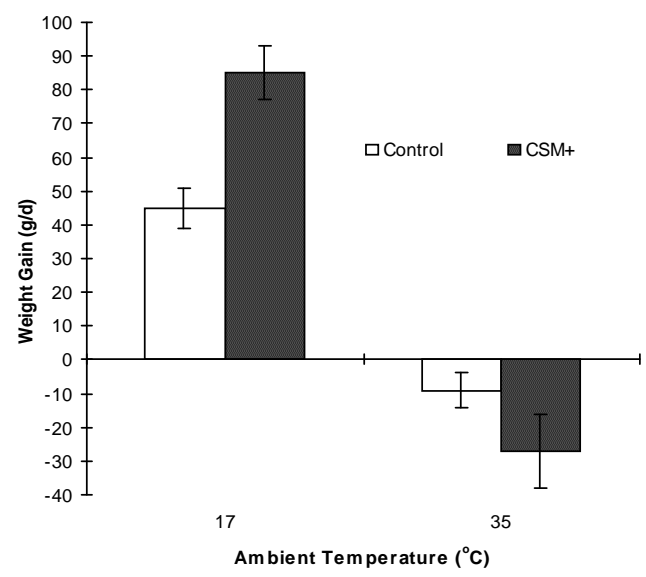

in this case. Concurrent information on fluid and particulate flow rates from the rumen would be needed to verify this suggestion.

\section{Liveweight gain}

The rate of LWG was significantly $(\mathrm{P}<0.01)$ reduced by high ambient temperature and the interaction between diet and ambient temperature was significant $(\mathrm{P}<0.01)$. At low temperature, lambs on the CSM+ diet grew significantly faster than those on the control diet. At high ambient temperature, on the other hand, those on the CSM+ diet did not perform better than those on the control diet, as shown in Figure 4, which illustrates the rates of LWG of the groups of lambs and their corresponding estimated ME intakes.

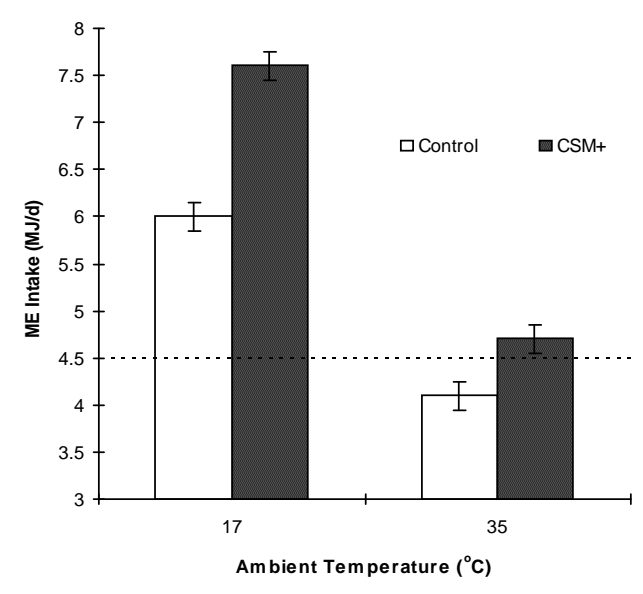

Figure 4. Effect of ambient temperature and diet on LWG and estimated ME intake of crossbred lambs in Experiment 1 (mean $\pm \mathrm{SE}, \mathrm{N}=4$; ---- = the calculated maintenance requirement).

It has been suggested that any positive response to bypass protein supplementation (which will vary with the RDP, UDP and soluble CHO levels in the basal diet) may be greater when ambient temperature increases (Leng, 1989). Bypass protein from CSM would be expected to provide additional amino acids for productive functions such as tissue growth. While the rate of liveweight gain in Experiment 1 was almost twice as fast on $\mathrm{CSM}+$ diet as on the control diet at low ambient temperature, differences were non significant at high temperature.

Apparently, any beneficial effects of CSM supplementation could not outweigh the negative effects on the sheep of the high ambient temperature and humidity in the current experiment. Regardless of diet, feed intake was significantly depressed at high ambient temperature. As a result, less digestible organic matter and less ME was ingested at high ambient temperature than under thermoneutral conditions. In fact, the ME intakes of lambs on the control and $\mathrm{CSM}+$ diets, estimated according to the energy density of feed [(0.16\%OMD)- 1.8; SCA, 1990], were 5.97 and $7.56 \mathrm{MJ} / \mathrm{d}$ at the low, and 4.13 and $4.69 \mathrm{MJ} / \mathrm{d}$ at the high ambient temperature, respectively (Figure 4). The calculated ME requirement for maintenance at thermoneutrality for lambs of this weight was $4.54 \mathrm{MJ} / \mathrm{d}$ (SCA, 1990) and thus the corresponding predicted liveweight changes are 39 and $82 \mathrm{~g} / \mathrm{d}$ at low temperature and -11 and $4 \mathrm{~g} / \mathrm{d}$ at high temperature. These first 3 predicted values were very close to the observed values of 45 and 85 , and -9 , 
respectively, but the last value (for sheep on the $\mathrm{CSM}$ at $35^{\circ} \mathrm{C}$ ) was higher than that observed. It has been reported that energy retention is reduced when animals are heat stressed (Ames and Brinks, 1977) indicating that maintenance energy requirement is increased during heat stress. In the present experiment, a higher ME requirement might have contributed to the loss of weight on both diets at high ambient temperature.

\section{CONCLUSION AND RECOMMENDATION}

The results of this experiment demonstrate that, consistent with general findings, high ambient temperature increases respiration rate, rectal temperature and water intake but reduces dry matter intake and live weight gain. Supplementation with $100 \mathrm{~g} / \mathrm{d}$ of CSM could not outweigh the depressing effects of constant high ambient temperature and humidity imposed in this experiment. The digestibility of the basal diet used was probably too low, and the sub-maintenance ME intake observed at high ambient temperature was probably the major factor affecting the loss of weight of sheep fed both the control and the $\mathrm{CSM}+$ diets. It is therefore recommended that under tropical conditions, ruminants consuming low quality forares are supplemented with source of bypass protein (such as cottonseed meal or copra meal) to minimise the negative impact of high ambient temperature and to improve ruminant productivity in the tropical regions.

\section{ACKNOWLEDGMENT}

This experiment was part of the PhD study of the first author who received scholarship funding support from AusAID.

\section{REFERENCES}

Ames, D.R. and D.R. Brink. 1977. Effect of temperature on lamb performance and protein efficiency ratio. Journal of Animal Science. 44:136-140.

Appleman, R.D. and D.J.Delouche. 1958. Behavioural, physiological and biochemical responses of goats to temperature, $0^{\circ}$ to $40^{\circ} \mathrm{C}$. Journal of Animal Science. 2:326-335.

Beede, D. K. and R. J. Collier. 1986. Potential nutritional strategies for intensively managed cattle during thermal stress. Journal of Animal Science. 62:543-554.
Bhattacharya, A. N. and F. Hussain. 1974. Intake and utilisation of nutrients in sheep fed different levels of roughage under heat stress. Journal of Animal Science. 38:877-886.

Bianca, W., J. D. Findlay, and J. A. Mclean. 1965. Responses of steers to water restriction. Research Veterinary Science 6: 38-55.

Christopherson, R. J. 1985. The thermal environment and the ruminant digestive system. In: Stress Physiology in Livestock. Yousef, M. K. (Ed). CRC Press, Inc. Boca Raton, Florida. pp.: 163-180

France, J. and R. C.Siddons. 1993. Volatile fatty acid production. In Quantitative Aspects of Ruminant Digestion and Metabolism. Forbes, J. M. and France, J. (eds.). CAB International. Cambridge, United Kingdom. pp.: 107-121.

Habeeb, A. A. M., I. F. M. Marai, and T. H. Kamal. 1992. Heat stress. In Farm Animals and the Environment. (Phillips, C. and D. Piggins, eds.) CAB International. Cambridge, United Kingdom. pp.: 27-47

Johnson, H. D. 1987. Bioclimates and livestock. In. Bioclimatology and the Adaptation of Livestock. World Animal Science B5. Johnson, H. D. (Ed.) Elsevier. Amsterdam. pp.:3-16.

Leng, R. A. 1989. Some factors influencing the efficiency of feed utilisation by ruminants with special reference to the tropics. In Recent Advances in Animal Nutrition in Australia. Farrell, D. J. (ed.). University of New England. Armidale. pp.:75-85.

Leng, R.A. 1990. Factors affecting the utilisation of 'poor-quality' forages by ruminants particularly under tropical conditions. Nutrition Research Reviews. 3:277-303.

Leng, R.A., N. Jessop and J. Kanjanapruthipong. 1993. Control of feed intake and the efficiency of utilisation of feed by ruminants. In Recent Advances in Animal Nutrition in Australia. Farrell, D. J. (ed.). University of New England. Armidale. pp.: 70-88.

McDowell, R. E., E. G.Moody, P. J.Van Soest, R. P. Lehmann and Ford, G. L. 1969. Effect of heat stress on energy and water utilisation of lactating cows. Journal of Dairy Science. 52:188-194.

Orskov, E. R. and N. A. MacLeod. 1990. Dietary-induced thermogenesis and feed evaluation in ruminants. Proceeding of the Nutrition Society. 49:227-237. 
Preston, T. R. and R. A. Leng. 1987. Matching Ruminant Production Systems with Available Resources in the Tropics and Subtropics. Penambul Books. Armidale.

Ryan, F. R., B. L. Jpiner, and T. A., Ryan Jr. 1985. Minitab Handbook. 2nd ed. PWS-KENT Publishing Company, Boston.

Yousef, M. K. and H. D. Johnson. 1985. Endocrine system and thermal environment. In Stress Physiology in Livestock. Vol. I. Basic Principles. CRC Press. Boca Raton, Florida. pp.: 133-141.
S.C.A. 1990. Feeding Standard for Australian Livestock, Ruminants. Standing Committee on Agriculture, Ruminants Subcommittee. CSIRO, Melbourne.

Yeates, N. T. M., T.N. Edey and M. K. Hill. 1975. Animal Science: Reproduction, Climate, Meat, Wool. Pergamon Press. Sydney. 